JOURNAL OF SECURITY AND SUSTAINABILITY ISSUES

ISSN 2029-7017 print/ISSN 2029-7025 online

2020 September Volume 10 Number 1

http://doi.org/10.9770/jssi.2020.10.1(11)

Scopus

\title{
THE INVESTMENT ENVIRONMENT MANAGEMENT SYSTEM IN THE FRAMEWORK OF LEGAL SUPPORT AS A FACTOR OF NATIONAL SAFETY
}

\author{
Iryna Panova ${ }^{1}$, Olha Andriiko², Liudmila Kysil ${ }^{3}$, Tetyana Kurylo ${ }^{4}$, Yuliya Uralova ${ }^{5}$ \\ ${ }^{1 *}$ Kharkiv National University of Internal Affairs, Kharkiv, L. Landau avenue, 27, Kharkiv, 61080, Ukraine \\ ${ }^{2,3}$ Institute of State and Law of National Academy of Sciences of Ukraine, \\ Trohsvyatitelskaya Street, 4, Kyiv,01001, Ukraine \\ ${ }^{4}$ Lviv State University of Internal Affairs, 26 Horodotska Street, Lviv, Lviv region, 79000, Ukraine \\ ${ }^{5}$ Vasyl' Stus Donetsk National University, st. 600-richchia, 21, Vinnytsia, 21021, Ukraine
}

E-mail: ${ }^{*}$ koaduep@gmail.com

Received 18 January 2020; accepted 30 June 2020; published 30 September 2020

\begin{abstract}
By specifying the components of the investment environment as a national safety factor that is a result of the impact of two elements - investment potential and investment risks; we generated the list of components of the investment environment of national economies, which give complex characteristics of its social, economical, and institutional factors; and held a complex analysis of investment environment of 93 countries under the condition of global development that made it possible to identify the groups of the most attractive, attractive, mid-attractive, relatively attractive and unattractive countries upon the investment environment factors. The study made it possible to build an authorial ranking of the world countries' investment environment, determined through the use of the human development integral index calculation methodology, adapted to investment activity. The hierarchy of the world countries was built upon the investment environment, in which Switzerland, Denmark, and Sweden are the leaders, while Mozambique, Mali, and Cameroon took the positions of the outsiders. The held study made it possible not only to carry out an analysis of asymmetric development of the world investment environment but also form the components of establishing an investment environment of the country, divide the countries into clusters upon the level of its development, mark factor loading, and offer the authorial ranking of the investment environment attractiveness. It was identified that developed countries also use state investment orders. The key role of the state in investment processes based on the example of the Japanese model requires a new, unprejudiced bureaucracy with an excellent reputation and uncompromising attitude to any manifestation of corruption.
\end{abstract}

Keywords: investment environment, national security, national economy, ranking, legal enforcement.

Reference to this paper should be made as follows: Panova, I., Andriiko, O., Kysil, L., Kurylo, T., Uralova, Y. 2020. The investment environment management system in the framework of legal support as a factor of national safety. Journal of Security and Sustainability Issues, 10(1): 149-162. http://doi.org/10.9770/jssi.2020.10.1(11)

JEL Classifications: F35; F42

\section{Introduction}

The gradual evolutionary development of the national economy requires the involvement of a maximum amount of investments that must be directed at creating an effective system of crediting small and medium-sized businesses, the development of the technology-enabled production of competitive products, transport infrastructure improvement, and the creation of new jobs. The main condition of the engagement of the direct investments is a positive investment environment that is determined as a set of conditions and factors, affecting the consciousness of a potential investor during decision making, concerning the beginning of investment activity. 
The key role in building a positive investment environment belongs to the legal basis of the investment activity, i.e. the aggregate of legal norms and other legal support tools needed to provide an efficient investment activity, the protection of rights and interests of investors, including a system of providing administrative services to entities, involved in investment activities, and legal guarantees of retaining and return of investments when necessary. This raises the need for a scientific generalization of legal support of a positive investment environment needed to improve public administration activity and its interaction with other entities of the investment activity.

The European integration processes include the adaptation of the national legislation to the European Union law, including the European-common legislation in the area of the investment activity. The positive experience of the European Union countries concerning the attraction of investments and establishing a generally positive investment environment makes it necessary to learn more about such experience and the introduction of its components in the national legislation and legal practice.

The provision of a maximum flow of investments to the national economy for the development of high technological production of competitive products, new jobs, and effective expansion of international markets becomes especially relevant under conditions of the globalization and EU integration processes. Before he makes a decision, a potential investor inspects the investment environment of a specific country, which is a complex interindustry category, worth an individual study, considering its theoretical and practical values.

The research objective is the generation of scientifically grounded conclusions, theoretical provisions, and practical recommendations, aimed at improvement of the ability to deliver good results and efficiency of the legal support mechanism of the investment environment.

\section{Literature Survey}

The genuine understanding of any legal phenomenon or a process is impossible without the study of the story behind its appearance, establishment, and development.

Legal regulation of the investment activity is connected to the interference of the state in the field of the market economy, setting standards that regulate capital investment procedures, acquisition of real estate, and other material and intangible valuables (assets) (Giang, M. H., et al. (2018); Khalatur, S., et al., 2020).

The establishment of the common market of the Western European countries grounds on the four fundamental principles, namely (Al-Louzi, R. (2017)): the freedom of manpower movement, the freedom of merchandise turnover, freedom of service turnover, and freedom of capital movement.

The entrenchment of the regulatory principles in the international agreement means that the member-states of the common market can adopt national legislation, including national legislation related to foreign investments in any form and content, as long as this legislation is consistent with the regulatory principle, mentioned in the international agreement (Battiston, S., et al. (2017)).

The freedom of movement of manpower, products, services, and capital is the fundamental nature of the European Union and the key factor of the positive investment environment provision. Being the common for all EU Member States, the legal-administrative support means of the investment activity ensure the adherence to the principle of legal certainty and guarantee potential investor protection and development of his investments (Chen, C., et al. (2018)).

The legislative and regulatory activities of public administration, as well as activity of the authoritative powers' subjects including an application of the rules of law (judicial and administrative practice), are the main forms of legal support of a positive investment climate (Flaherty et al., 2017; Ohotina et al, 2018). One should pay particular attention to the importance of public administration activity concerning the interpretation of the rules of law, regulating questions on investment activity. 
Basically, the scientists distinguish the following investment policy models of the developed countries:

the investment policy model in the USA mostly focuses on implementation of the economic freedom and economic liberalization principles rather than on serious direct interference in the economic process (Tetiana, H., et al. (2019));

speaking of the model in the United Kingdom, it is aimed, primarily, at protecting the rights of the capital owners and ensuring the most unhampered and fast capital accumulation for the convenience of the capital owners (Drobyazko, S., et al. (2019a), Drobyazko, S., et al. (2019b));

the investment policy model in Germany is characterized by creative directness concerning domestic financial institutions and strict progressive taxation (Gebrezgabher, S., Taron, A., \& Amewu, S.) (2019);

the model has a distinct division between direct and other foreign capital investments in France. It applies a more liberal regulation concerning the last-mentioned ones (Veganzones-Varoudakis, M. A., \& Nguyen, H. T. M. (2018));

regarding Japan, the investment policy model makes an emphasis on the state financing of projects; it grounds on an active partnership between the state and private investors (Karpenko, L., et al. (2018); Panchenko, V., et al. (2019)).

Nonetheless, the question regarding the administrative-legal support for ensuring a positive investment environment is revealed in the legal science on a peacemeal basis, in the framework of more generalized topics which increases the need for holding a study.

\section{Methods}

The research includes a system of approaches, principles, and methods of scientific cognition. Their choice was conditioned by the research objective and tasks, considering its object and subject. The research methodology grounds on the organic combination of philosophical (the laws of dialectics and metaphysics, objectivity and historicism principles), general schientific (logical method, system and structure-functional method, statistical and sociological methods), and special legal methods of study, among which is the legal logic method, formallegal method (method of legal dogmatic), methods of comparative law science, and legal modeling.

To identify the positive experience of administrative-legal support for a positive investment environment in the developed countries, we use the methodology of comparative legal studies. The relevant directions of improving the system of legal arrangements of providing a positive investment environment are determined through the use of a logical method, a systematic method, and legal statistics and legal modeling methods.

During the study of administrative-legal support for a positive investment environment, it makes sense to use a "double negative" technique. In particular, the researcher can state that a specific form of an investment activity does not need legal regulation and control by the state, but in the course of a scientific search, he reaches a gradual rejection of such an objection by discovering specific facts, examples, and evidence, demonstrating the need for the government to interfere and carry out legal regulation of the corresponding type of investment relationship.

\section{Results}

To assess the investment environment of the national economies, it is proposed to use the data of the world rankings, the methodology of which demonstrates the balance between the investment potential and investment risks - the lead countries of those rankings have potential advantages and minimal risks, while the outsider countries, on the contrary, have more investment risks with insufficient potential investment opportunities. 
We selected the data of the following rankings, Figure 1, as part of the investment environment, which give complex characteristics to social, economic, and institutional factors of building an investment environment.

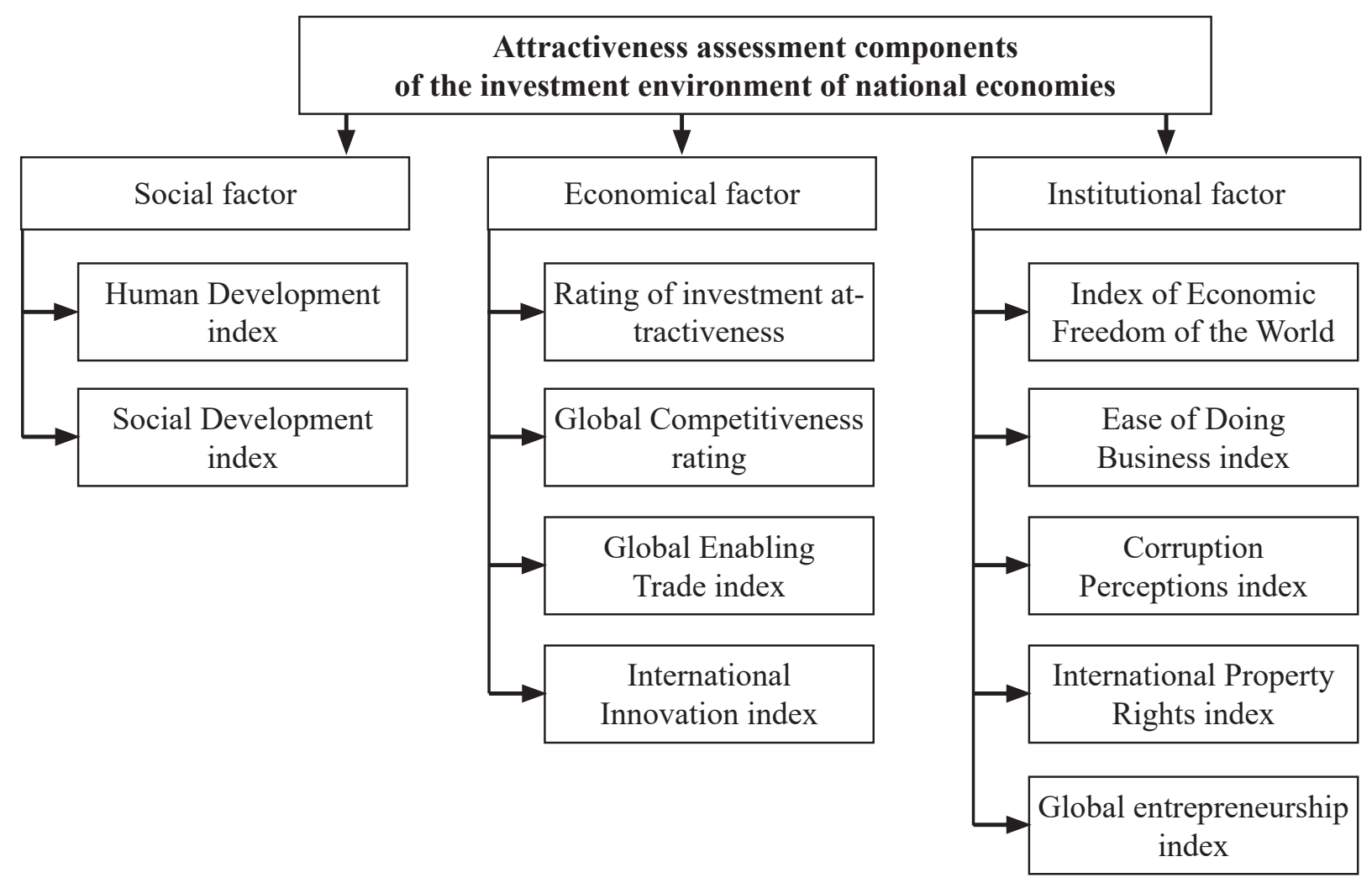

Figure 1. Components of attractiveness assessment of investment environment of national economies

Let us have a closer look at each of the mentioned rankings.

The Human Development Index (HDI) is an outcome indicator for assessment of long-term human development progress in three main areas: long-term and healthy living; access to knowledge; a decent standard of living.

Table 1 demonstrates TOP 10 leading and outsider countries of the index.

Table 1. TOP 10 leading and outsider countries of the human development index in 2018

\begin{tabular}{|l|l|l|c|}
\hline Leading country of the index & Index & Outsider country of the index & Index \\
\hline Norway & 0,953 & Niger & 0,354 \\
\hline Switzerland & 0,944 & CAR & 0,367 \\
\hline Australia & 0,939 & South Sudan & 0,388 \\
\hline Ireland & 0,938 & Chad & 0,404 \\
\hline Germany & 0,936 & Burundi & 0,417 \\
\hline Iceland & 0,935 & Sierra Leone & 0,419 \\
\hline Hong Kong & 0,933 & Burkina Faso & 0,423 \\
\hline Sweden & 0,933 & Mali & 0,427 \\
\hline
\end{tabular}

Source: grounds based on the data of http://hdr.undp.org/en/content/human-development-index-hdi

The Social Development index is a composite indicator, measuring the achievements of the world countries in terms of public welfare and social progress. The index does not include indicators of the world countries' economic development (GDP, etc.), but aims to assess public welfare in the countries. 
Table 2 reflects TOP 10 leading and outsider countries of the index.

Table 2. TOP 10 leading and outsider countries of the Social Development index in 2018

\begin{tabular}{|c|c|c|c|}
\hline Leading country of the index & Index & Outsider country of the index & Index \\
\hline Denmark & 90,1 & CAR & 26,58 \\
\hline Norway & 90,1 & Chad & 27,8 \\
\hline Switzerland & 90,03 & Afghanistan & 31,9 \\
\hline Iceland & 89,99 & Eritrea & 32,76 \\
\hline Finland & 89,88 & Democratic Republic of the Congo & 35,77 \\
\hline Luxembourg & 89,32 & Niger & 37,02 \\
\hline Netherlands & 89,24 & Burundi & 37,4 \\
\hline Sweden & 89,14 & Papua New Guinea & 37,83 \\
\hline
\end{tabular}

Source: grounds based on the data of https://www.socialprogress.org/

BDO International Business Compass measures the attractiveness of the country as a multidimensional concept in three dimensions: economic, political, and socio-cultural.

Table 3 demonstrates TOP 10 leading and outsider countries of the ranking.

Table 2. TOP 10 leading and outsider countries of the Rating of the Investment Attractiveness in 2018

\begin{tabular}{|c|c|c|c|}
\hline Leading country of the index & Index & Outsider country of the index & Index \\
\hline Singapore & 85,1 & North Korea & 27,76 \\
\hline Hong Kong & 84,08 & Venezuela & 29,96 \\
\hline Switzerland & 81,84 & Sudan & 30,81 \\
\hline Netherlands & 80,14 & Afghanistan & 33,47 \\
\hline Ireland & 78,81 & Eritrea & 33,56 \\
\hline Denmark & 78,8 & CAR & 34,24 \\
\hline Norway & 78,22 & Chad & 35,61 \\
\hline United Kingdom & 77,06 & Democratic Republic of the Congo & 36,6 \\
\hline
\end{tabular}

Source: grounds based on the data of https://www.bdo-ibc.com/index.php?id=35

The Global Competitiveness Index consists of 113 variables, which provide a detailed characterization of the competitiveness of the world countries, which are at different levels of economic development. All variables are clustered into 12 control benchmarks, which determine national competitiveness: the quality of institutions; infrastructure; macroeconomic stability; healthcare and primary education, high education and vocational training; efficiency of the goods and services markets; effectiveness of the labor market; the development of the financial market; the level of technological development; the size of the domestic market; the competitiveness of the companies; and the innovation potential.

Table 4 shows TOP 10 leading and outsider countries of the ranking.

Table 4. TOP 10 leading and outsider countries of the Global Competitiveness rating in 2018

\begin{tabular}{|c|c|c|c|}
\hline Leading country of the index & Index & Outsider country of the index & Index \\
\hline USA & 85,641 & Chad & 35,52 \\
\hline Singapore & 83,478 & Yemen & 36,396 \\
\hline Germany & 82,839 & Haiti & 36,451 \\
\hline Switzerland & 82,586 & Angola & 37,056 \\
\hline Japan & 82,468 & Burundi & 38,241 \\
\hline Netherlands & 82,38 & Democratic Republic of the Congo & 38,8 \\
\hline Hong Kong & 82,251 & Sierra Leone & 39,754 \\
\hline
\end{tabular}

Source: grounds based on the data of http://www3.weforum.org/docs/GCR2018/05FullReport/TheGlobalCompetitivenes sReport2018.pdf 
The Global Enabling Trade Index is calculated based on the analysis of the indicators of the national economies' openness to international commerce, which characterize market accessibility, administrative management at the border, transport and communication infrastructure, as well as the country's business environment. The data analysis of this study makes it possible to determine the way the country removes the barriers on the way to international integration; its ability to promote commerce and solve systemic problems to improve the situation.

Table 5 shows TOP 10 leading and outsider countries of the ranking.

Table 5. TOP 10 leading and outsider countries of the Global Enabling Trade index in 2018

\begin{tabular}{|c|c|c|c|}
\hline Leading country of the index & Index & Outsider country of the index & Index \\
\hline Singapore & 5,97 & Venezuela & 2,85 \\
\hline Netherlands & 5,7 & Chad & 2,93 \\
\hline Hong Kong & 5,66 & Yemen & 2,95 \\
\hline Luxembourg & 5,63 & Democratic Republic of the Congo & 3,03 \\
\hline Sweden & 5,61 & Iran & 3,16 \\
\hline Finland & 5,6 & Mauritania & 3,18 \\
\hline Austria & 5,52 & Cameroon & 3,24 \\
\hline
\end{tabular}

Source: grounds based on the data of https://reports.weforum.org/global-enabling-trade-report-2018/

The International Innovation Index assesses the elements of the national economies, hosting innovation processes, in particular, the institutions, human capital, research activity, the infrastructure, the level of the market and business development. It considers over 80 parameters, among which is the number of applications for intellectual property rights, the creation of mobile applications, scientific and technical publications, and the volume of expenses for education.

Table 6 reflects TOP 10 leading and outsider countries of the index.

Table 6. TOP 10 leading and outsider countries of the International Innovation index in 2018

\begin{tabular}{|c|c|c|c|}
\hline Leading country of the index & Index & Outsider country of the index & Index \\
\hline Switzerland & 68,4 & Yemen & 15,04 \\
\hline Netherlands & 63,32 & Togo & 18,91 \\
\hline Sweden & 63,08 & Burkina Faso & 18,95 \\
\hline United Kingdom & 60,13 & Ivory Coast & 20,57 \\
\hline Singapore & 59,83 & Niger & 20,61 \\
\hline USA & 59,81 & Benin & 20,66 \\
\hline Finland & 59,63 & Zambia & 20,71 \\
\hline Denmark & 58,39 & Guines & \\
\hline
\end{tabular}

Source: grounds based on the data of https://reports.weforum.org/global-enabling-trade-report-2018/

Economic Freedom of the World index grounds on 10 indexes: freedom of business; freedom of trade; tax freedom; state expenses; monetary freedom; freedom of investments; financial freedom; protection of property rights; freedom from corruption; freedom of work relationship.

Table 7 demonstrates TOP 10 leading and outsider countries of the index. 
Table 7. TOP 10 leading and outsider countries of the index of the countries' involvement to the Economic Freedom of the World index in 2018

\begin{tabular}{|c|c|c|c|}
\hline Leading country of the index & Index & Outsider country of the index & Index \\
\hline Hong Kong & 8,97 & Venezuela & 2,88 \\
\hline Singapore & 8,84 & Libya & 4,74 \\
\hline New Zealand & 8,49 & Argentina & 4,84 \\
\hline Switzerland & 8,39 & Algeria & 4,99 \\
\hline Ireland & 8,07 & Democratic Republic of the Congo & 5,02 \\
\hline USA & 8,03 & Syria & 5,02 \\
\hline Georgia & 8,02 & CAR & 5,11 \\
\hline Mauritius & 8,01 & Angola & 5,17 \\
\hline
\end{tabular}

Source: grounds based on the data of https://www.fraserinstitute.org/studies/economic-freedom-of-the-world-2018-annual-report

Ease of Doing Business Index grounds only on the study and quantification of the laws, regulations, and rules, related to doing business. It is based on ten internal indicators: the beginning of business activity; work with building permits; obtaining electricity; property records; credit obtaining; protection of the investor's rights; payment of taxes; international trade; contract solicitation; and business closure.

Table 8 reveals TOP 10 leading and outsider countries of the index.

Table 8. TOP 10 leading and outsider countries of the index of the Ease of Doing Business index in 2018

\begin{tabular}{|c|c|c|c|}
\hline Leading country of the index & Index & Outsider country of the index & Index \\
\hline Singapore & 86,55 & Somali & 19,98 \\
\hline New Zealand & 84,57 & Eritrea & 22,87 \\
\hline Denmark & 84,06 & Venezuela & 30,87 \\
\hline The Republic of Korea & 83,92 & South Sudan & 32,86 \\
\hline Hong Kong & 83,44 & Yemen & 33,00 \\
\hline USA & 82,54 & Lybia & 33,21 \\
\hline United Kingdom & 82,22 & CAR & 34,86 \\
\hline Norway & 82,16 & Afghanistan & 36,19 \\
\hline
\end{tabular}

Source: grounds based on the data of https://www.doingbusiness.org/en/rankings

Corruption Perceptions Index - the countries are ranked upon the index of the corruption level, which grounds on the estimates of the businessmen and analysts.

Table 9 shows TOP 10 leading and outsider countries of the index.

Table 9. TOP 10 leading and outsider countries of the Corruption Perceptions index in 2018

\begin{tabular}{|c|c|c|c|}
\hline Leading country of the index & Index & Outsider country of the index & Index \\
\hline New Zealand & 89 & Somali & 9 \\
\hline Denmark & 88 & South Sudan & 12 \\
\hline Norway & 85 & Syria & 14 \\
\hline Finland & 85 & Afghanistan & 16 \\
\hline Switzerland & 85 & Yemen & 16 \\
\hline Singapore & 84 & Sudan & 17 \\
\hline Sweden & 84 & Guines-Bissau & 17 \\
\hline
\end{tabular}

Source: grounds based on the data of https://www.transparency.org/news/feature/corruption_perceptions_index_2018\#table 
International Property Rights Index. The assessment of the right and possibility of the citizens to have private property was carried out upon three main components: legal and political environment, material property rights, and intellectual property rights.

Table 10 demonstrates TOP 10 leading and outsider countries of the index.

Table 10. TOP 10 leading and outsider countries of the index of the International Property Rights index in 2018

\begin{tabular}{|c|c|c|c|}
\hline Leading country of the index & Index & Outsider country of the index & Index \\
\hline Finland & 8,692 & Haiti & 2,734 \\
\hline New Zealand & 8,632 & Yemen & 2,793 \\
\hline Switzerland & 8,619 & Venezuela & 3,367 \\
\hline Norway & 8,45 & Bangladesh & 3,637 \\
\hline Singapore & 8,405 & Pakistan & 3,745 \\
\hline Sweden & 8,397 & Democratic Respublic of the Congo & 3,771 \\
\hline Australia & 8,329 & Chad & 3,778 \\
\hline Netherlands & 8,325 & Burundi & \\
\hline
\end{tabular}

Source: grounds based on the data of https://www.internationalpropertyrightsindex.org/

The global entrepreneurship index is calculated based on how the country promotes entrepreneurial development (i.e. introduction of innovations, conditions for the functioning of small businesses, etc.).

Table 11 shows TOP 10 leading and outsider countries of the index.

Table 11. TOP 10 leading and outsider countries of the Global entrepreneurship index in 2018

\begin{tabular}{|c|c|c|c|}
\hline Leading country of the index & Index & Outsider country of the index & Index \\
\hline USA & 83,6142 & Chad & 10,97868 \\
\hline Switzerland & 80,4472 & Mauritania & 11,8262 \\
\hline Canada & 79,2453 & Burundi & 11,8365 \\
\hline United Kingdom & 77,7543 & Bangladesh & 12,2156 \\
\hline Australia & 75,4537 & Malavi & 12,297 \\
\hline Denmark & 74,3097 & Sierra Leone & 12,8524 \\
\hline Iceland & 74,1506 & Uganda & 12,9123 \\
\hline Ireland & 73,7173 & Guinea & \\
\hline
\end{tabular}

Source: grounds based on the data of https://thegedi.org/2018-global-entrepreneurship-index/

Table 12 demonstrates the data, based on which, it is possible to conclde, concerning the great significance of a social factor for the countries of the first cluster. All other factors have almost the same influence on the formation of the investment environment.

Table 12. Investment environment attraction of the world countries ranking in 2018

\begin{tabular}{|c|c|c|c|c|c|l|}
\hline Cluster & Characterystics & $\begin{array}{c}\text { Social } \\
\text { factor }\end{array}$ & $\begin{array}{c}\text { Economical } \\
\text { factor }\end{array}$ & $\begin{array}{c}\text { Institutional } \\
\text { factor }\end{array}$ & $\begin{array}{c}\text { Overall } \\
\text { ranking }\end{array}$ & Countries \\
\hline 1 & $\begin{array}{c}\text { The most } \\
\text { attractive }\end{array}$ & 0,940808 & 0,754488 & 0,678862 & $1,203-1,371$ & $\begin{array}{l}\text { Switzerland, Denmark, Sweden, the } \\
\text { United Kingdom, Netherlands, the USA, } \\
\text { Singapore, Finland, Canada, Germany, } \\
\text { Ireland, Australia, Norway, New Zealand, } \\
\text { Iceland, Austria, Japan, Franse, Israel }\end{array}$ \\
\hline
\end{tabular}




\begin{tabular}{|c|c|c|c|c|c|c|}
\hline 2 & Attractive & 0,8194265 & 0,8639465 & 0,713691 & $1,001-1,190$ & $\begin{array}{l}\text { Republic of Korea, Esonia, Belgium, } \\
\text { UAE, Spain, Czech Republic, Slovenia, } \\
\text { Portugal, Chile, Lithuania, Cuprus, } \\
\text { Poland, Italy, Qatar, Slovakia, Latvia, } \\
\text { Hungary, Malaysia, Uruguay, Costa Rica, } \\
\text { Romania, Croatia, Greece, Oman }\end{array}$ \\
\hline 3 & Mid-attractive & 0,8669285 & 0,8349358 & 0,800897 & $0,904-0,988$ & $\begin{array}{l}\text { Georgia, China, Saudi Arabia, Turkey, } \\
\text { Montenegro, Jordan, Bulgary, Panama, } \\
\text { Thailand, Botswana, Peru, Mexico, RSA, } \\
\text { Tunisia, Russia, Kazakhstan, Albany, } \\
\text { Armenia }\end{array}$ \\
\hline 4 & $\begin{array}{l}\text { Relatively } \\
\text { attractive }\end{array}$ & 0,9008285 & 0,896751 & 0,841852 & $0,804-0,881$ & $\begin{array}{l}\text { Morocco, Argentina, Brasil, Indonesia, Sri } \\
\text { Lanka, Ukraine, Philippines, Moldova, } \\
\text { the Dominican Republic, Lebanon, } \\
\text { India, Ecuador, Rwanda, Iran, Salvador, } \\
\text { Paraguay, Guatemala }\end{array}$ \\
\hline 5 & Unattractive & 0,991776 & 0,9634988 & 0,938447 & $0,632-0,796$ & $\begin{array}{l}\text { Egypt, Ghana, Kenya, Algeria, Honduras, } \\
\text { Senegal, Tanzania, Benin, Pakistan, } \\
\text { Bangladesh, Malawi, Nigeria, Cameroon, } \\
\text { Mali, Mozambique }\end{array}$ \\
\hline
\end{tabular}

Source: Designed by the authors

Thus, the held study made it possible not only to form the components of building the investment environment of the country but also to divide the world countries into clusters upon the level of its development, mark factor loading, and offer the authorial ranking of the investment environment attractiveness.

The successful long-term experience of investment attraction in the European Union countries demonstrates the high level of confidence from investors and the stability of the Europe-wide normal legal acts, which drive the norms of national legislation out. The compliance with the principle of juridical security is one of the main guarantees of a positive investment environment in the civilized countries, and the main task of public administration in Ukraine is the creation of all legislative and law enforcement conditions for compliance with this the previously-mentioned principle. All this raises the need for special scientific research of experience on assuring the administrative and legal support of a positive investment environment in developed countries; and the identification of its positive components, which can be taken for introduction in national legislation and legal practice.

The experience of legal regulation of collective investment institutions deserves particular attention. For example, the institute of collective investment in England consists of trusts and unit trusts. The first-mentioned ones are the institutes of collective investment of a closed type, which do not have the right to constantly issue or repurchase their units, and their shares are listed on the stock exchange. Unit-trusts have a more different nature.

By investing in them, the investor receives a certificate about the share payment. In recent times, the unit-trusts, operating based on the specific British trust law, gave place to the open investment companies, established based on the 1985 Directive of the European Union "Collective investment undertaking in transferable securities," which declares common unified principles of establishing collective investment institutions. This is because investment companies are easier to manage, the investors better understand the structure of pricing, and the shares of such companies are easier to sell outside the UK. As of today, the assets of unit trusts constitute 141 billion pounds sterling. Under the condition of their development, one can expect significant growth of this indicator (Tollington, S., et al. (2017)).

The growth indicators of the collective investment industry in other European countries are also rather significant and speak for themselves. Thus, at some of the "young" European markets, for example, Portugal and Spain, one registered a more than $40 \%$ annual growth ratio of assets value of the investment trusts. Almost $25 \%$ of French families own investment trust shares. The corporate investment funds of the open type are the most widespread form of putting up collective investment in France. They bear the name of the investment companies with variable capital (SICAV). 
The investment environment in Germany also deserves attention. The specificity of its economy is that even financial institutions, investing in the securities market, are regulated by the same legislation as the banks. The Law on Investment Companies (KAGG) is the foundation for the functioning of the investment funds. According to it, the investment companies are recognized as the credit institutions, and they comply with all the corresponding legislative forms, including the Depository Institutions Act. They are subject to control by the Federal Credit Institutions Supervision Authority (Jimborean, R., \& Kelber, A. (2017)).

The economy of Japan is characterized by a significant role of banks in collective investment. The main share of the collective investment capital is managed there by seven largest trust banks - specialized structures, performing both the functions of trust management of depositors' funds and organization of collective investment. The functions of these institutions cover management of funds, accumulated in the trust accounts by investing them in securities; the use of such accounts for the organization of corporate lending; the management of the pension funds and other institutional investors' funds, the administration of the formed portfolios of the clients' securities, real estate, and other functions.

The most diverse collective investment in terms of the organization forms and scale is observed in the USA, for which the prohibition or severe capital restrictions for the banks' securities transactions are traditional, as these financial instruments are the optimal assets for placing the funds of collective investment institutions. The banks of America, including the investment banks, are one of the elements of the collective investment system, they are the managers of their funds and entities, accumulating the costs.

Non-banks - the institutions of collective investment fall into three main types:

Face Amount Companies;

United Investment Trust Companies;

Management Companies.

The first companies emit certificates with a determined nominal cost, which by its nature is a type of a contract between an investor and a company. They determine the face value that is equivalent to the volume of the investor's finances, the validity of a contract related to their management, the management terms, including the terms of payment of the basic investment amount and income, which are applied after the contract expiration. Thus, the FA-companies act as a debtor to investors and bear risks from investing the capital of the clients in the financial assets. The company has to pay the value of the certificates within 8 years. The average value of the nominal is approximately 3.000 US dollars. Investment objects - the mortgage, crediting of construction, and securities. These companies were very popular among investors in the 30 s of the XX century, and in the mid-60s, there were only five companies with cash value certificates on the market, $94 \%$ of the total funds' accumulation of which belonged to "Investor Syndicate of America," which is still active these days.

The second type of investment funds is the joined trusts that are formed based on a trust agreement, i.e. a contract for managing an investment portfolio on behalf of the owner. When creating them, one determines the structure of the portfolio that remains unchanged in the future. The cash equivalent of the future portfolio is accumulated through selling equity participation certificates to the investors. The fund's maintenance functions are carried out by the so-called depositary, the status of which is defined as the first principal's status. It is he who brings the initial capital in when creating a trust (at least 100.000 US dollars), in exchange for which, he receives the corresponding package of certificates, which are distributed among small investors.

The number of investment funds of the third type - managerial companies - was reaching 5070, while the cost of its assets -2.135 mlrd US dollars. During the past two decades, the quantitative development of the collective investment institutions in the USA has taken place at the expense of the open-ended management companies. (Giechaskiel, B., et al. (2018)).

One of the main factors that contributed to the activation of investment processes in post-war Western Europe 
is the formation of the objectives and principles of the investment law, based on the objectives and principles of the international law in general and the establishment of the European Economic Community (EEC). The Roman Treaty Establishing the European Economic Community became the foundation for the harmonization of the law. It was adopted on 25 March 1957, which (after the Treaty of Lisbon came into action, it is called the Treaty on the Functioning of the European Union) determined as its main objectives in section 2 to promote in the framework of the entire Community harmonious, balanced, and stable development of the economic activity, a high level of employment and social protection, gender equality, stable and disinflationary growth, a high level of competitiveness and convergence of the economic indicators, a high level of environmental protection and improvement, the improvement of the living standards and quality of life, economic and social cohesion, and collective responsibility of the member countries (Geddes, R. R., \& Reeves, E. (2017)).

The creation of the Common Market in Western Europe grounds on the four fundamental principles, namely: the freedom of movement of manpower, the freedom of circulation of goods, the freedom of circulation of services, and the freedom of capital flow. The establishment of the regulatory principles in the international treaty means that member countries of the Common Market can adopt national legislation, including the national legislation on foreign investments in any form and content, as long as that legislation is consistent with the regulatory principle, specified in the international treaty.

\section{Discussion}

The main methods of investment activity regulation in such countries like the United Kingdom, France, Germany, and Japan are the following ones:

the regulation (support or restriction) of the general amount of investments (it is the main method of managing the investment process that is carried out through the loan interest, monetary, tax, and depreciation policies);

selective promotion of the capital investment in particular enterprises, industries, and areas of activity using credit and tax benefits, for example, through an investment loan;

a direct administrative intervention in the investment process for the introduction or withdrawing certain productive capacities through the coordination of the plans and actions of the biggest corporations.

In the developed countries, the role of a regulating instrument also belongs to the state investment appropriation request, to which the countries call for in the following cases:

there are differences between the interests of companies, a private capital, and national interests;

the entrepreneurs and the capital owners are not much interested in solving external-economic state problems from an economic point of view;

the government or local authorities see by themselves the need to support the employment of individual firms and corporations in periods of crisis and downturn;

the balancing of economic and negative social consequences of the market relationship in the area of investments;

the formation of priority of investment inputs from the point of view of nationwide or regional interests;

the cuts of the required materials and goods deficits that occur due to market distortions; the prevention of failure to comply with the undertaken external-economic state obligations.

\section{Conclusions}

We specified the components of the investment climate, which is the result of the influence of two elements: investment potential and investment risks - the lower is the level of investment risks, the more fully the investment potential can be used. We also generated the list of components of the investment environment of national economies, which give a complex characteristics of its social, economical, and institutional factors: the Human Development index; the Social Development index; the Rating of Investment Attractiveness; the Global Competitiveness rating; the Global Enabling Trade index; the International Innovation index; the Ease of Doing Business index; the Corruption Perception index; the International Property Rights Index; and the 


\section{Global Entrepreneurship index.}

One held a complex analysis of the investment environment of 93 countries under the condition of global development using a cluster analysis, which made it possible to identify the groups of the most attractive, attractive, mid-attractive, relatively attractive, and unattractive countries upon the investment environment. A specific emphasis was put on a significant regional asymmetry of the investment environment attractiveness, namely: the European countries have the highest level of attractiveness of the investment environment and the absence of the investment-unattractive countries. In Africa, one can observe a contrary situation, when the most attractive countries for investment are absent. Most countries in Asia, Oceania, and America belong to relatively attractive countries for investing.

The study of the positive experience of the administrative and legal support for ensuring of a positive investment environment in the developed countries made it possible to conclude the need for a systematization of national legislation in the area of investments and investment activity, taking into account a positive experience of the developed EU countries, the USA, Japan, and consideration of norms and principles of the European Union law. A single consolidated act should become the result of such systematization. It will regulate all major investment activity issues, which will ensure compliance with the principle of legal certainty in this area. Each active and potential investor should get clear and effective instruments for its activity and investment protection, as well as guarantees of return on his investments when it is necessary.

It was noted that the above-given list of the perspective directions on the improvement of the administrative and legal regulation of the investment activity is not exhaustive and requires further study in the framework of the administrative law doctrine.

\section{References}

Al-Louzi, R. (2017). Bilateral Investment Treaties as Tools for Enhancing Foreign Investment Climate and Increasing Competitiveness. Manchester J. Int'l Econ. L., 14, 69. Available at: https://heinonline.org/HOL/LandingPage?handle=hein.journals/ mjiel14\&div $=8 \&$ id $=\&$ page $=$

Battiston, S., Mandel, A., Monasterolo, I., Schütze, F., \& Visentin, G. (2017). A climate stress-test of the financial system. Nature Climate Change, 7(4), 283-288. Available at: https://www.nature.com/articles/nclimate3255

BDO International Business Compass. Available at: https://www.bdo-ibc.com/index.php?id=35

Chen, C., Hellmann, J., Berrang-Ford, L., Noble, I., \& Regan, P. (2018). A global assessment of adaptation investment from the perspectives of equity and efficiency. Mitigation and adaptation strategies for global change, 23(1), 101-122. Available at: https://link.springer. com/article/10.1007/s11027-016-9731-y

Corruption Perceptions Index. Available at: https://www.transparency.org/news/feature/corruption_perceptions_index_2018\#table

Drobyazko, S., Hryhoruk, I., Pavlova, H., Volchanska, L., \& Sergiychuk, S. (2019). Entrepreneurship innovation model for telecommunications enterprises. Journal of Entrepreneurship Education. Available at: https://www.abacademies.org/articles/entrepreneurshipinnovation-model-for-telecommunications-enterprises-8097.html

Drobyazko, S., Okulich-Kazarin, V., Rogovyi, A., \& Marova, S. (2019). Factors of influence on the sustainable development in the strategy management of corporations. Academy of Strategic Management Journal. Available at: https://www.abacademies.org/articles/ factors-of-influence-on-the-sustainable-development-in-the-strategy-management-of-corporations-8623.html

Ease of Doing Business Index. Available at: https://www.doingbusiness.org/en/rankings

Economic Freedom of the World. Available at: https://www.fraserinstitute.org/studies/economic-freedom-of-the-world-2018-annualreport

Exports of goods and services. https://data.worldbank.org/indicator/BX.GSR.GNFS.CD

Flaherty, M., Gevorkyan, A., Radpour, S., \& Semmler, W. (2017). Financing climate policies through climate bonds-A three stage model and empirics. Research in International Business and Finance, 42, 468-479. https://doi.org/10.1016/j.ribaf.2016.06.001 
Gebrezgabher, S., Taron, A., \& Amewu, S. (2019). Investment climate indicators for waste reuse enterprises in developing countries: Application of analytical hierarchy process and goal programming model. Resources, Conservation and Recycling, 144, $223-232$. https://doi.org/10.1016/j.resconrec.2019.01.049

Geddes, R. R., \& Reeves, E. (2017). The favourability of US PPP enabling legislation and private investment in transportation infrastructure. Utilities Policy, 48, 157-165. https://doi.org/10.1016/j.jup.2017.07.002

Giang, M. H., Xuan, T. D., Trung, B. H., Que, M. T., \& Yoshida, Y. (2018). Impact of investment climate on total factor productivity of manufacturing firms in Vietnam. Sustainability, 10(12), 4815. https://doi.org/10.3390/su10124815

Giechaskiel, B., Lahde, T., Suarez-Bertoa, R., Clairotte, M., Grigoratos, T., Zardini, A., ... \& Martini, G. (2018). Particle number measurements in the European legislation and future JRC activities. Combustion Engines, 57. Available at: http://yadda.icm.edu.pl/baztech/ element/bwmeta1.element.baztech-028f0521-7466-4ce3-a8e7-d44753f8e332

Global entrepreneurship index. Available at: https://thegedi.org/2018-global-entrepreneurship-index/

Human Development Index. Available at: http:/hdr.undp.org/en/content/human-development-index-hdi

International Property Rights Index. Available at: https://www.internationalpropertyrightsindex.org/

Jimborean, R., \& Kelber, A. (2017). Foreign direct investment drivers and growth in Central and Eastern Europe in the aftermath of the 2007 global financial crisis. Comparative Economic Studies, 59(1), 23-54. https://doi.org/10.1057/s41294-016-0018-9

Khalatur, S., Khaminich, S., Budko, O., Dubovych, O., \& Karamushka, O. (2020). Multiple system of innovation-investment decisions adoption with synergetic approach usage. Entrepreneurship and Sustainability Issues, 7(4), 2745-2763. http://doi.org/10.9770/ jesi.2020.7.4(12)

Karpenko, L., Serbov, M., Kwilinski, A., Makedon, V., \& Drobyazko, S. (2018). Methodological platform of the control mechanism with the energy saving technologies. Academy of Strategic Management Journal, 17(5), 1939-6104-17-5-271: 1-7. Retrieved from https://www.abacademies.org/articles/Methodological-platform-of-the-control-mechanism-1939-6104-17-5-271.pdf

Klochko, A.N., Kulish, A.N., Reznik, O.N. (2016). The social basis of criminal law protection of banking in Ukraine. Russian journal of criminology, 10 (4), pp. 790-800. https://doi.org/10.17150/2500-4255.2016.10(4).790-800

Ohotina, A., Lavrinenko, O., Gladevich, J. \& Lazdans, D. (2018). The investment climate in Latvia's, Lithuania's and Belarus's cross-border regions: the subjective-objective assessment. Entrepreneurship and Sustainability Issues, 6(2), 767-780. http://doi. org/10.9770/jesi.2018.6.2(20)

Panchenko V., Ilyina A., Mihus I., Vavrin M., Karpenko Yu. (2019). The role of investment strategy in the strategic management system of service companies // Academy of Strategic Management Journal. - Volume 18. - Special Issue 1. - 2019. URL: https://www.abacademies. org/articles/The-role-of-investment-strategy-in-the-strategic-management-system-of-service-Companies-1939-6104-18-SI-1-489.pdf

Tetiana, H., Chernysh O., Levchenko, A., Semenenko, O., Mykhailichenko H. (2019). Strategic Solutions for the Implementation of Innovation Projects. Academy of Strategic Management Journal. Volume 18, Special Issue 1. Available at: https://www.abacademies. org/articles/Strategic-solutions-for-the-implementation-of-innovation-projects-1939-6104-18-SI-1-444.pdf

The Global Competitiveness Index. Available at: http://www3.weforum.org/docs/GCR2018/05FullReport/TheGlobalCompetitivenes sReport2018.pdf

The Global Enabling Trade Index. Available at: https://reports.weforum.org/global-enabling-trade-report-2018/

The International Innovation Index. Available at: https://www.wipo.int/edocs/pubdocs/en/wipo_pub_gii_2018.pdf

The Social Progress Index. Available at: https://www.socialprogress.org/

Tollington, S., Turbé, A., Rabitsch, W., Groombridge, J. J., Scalera, R., Essl, F., \& Shwartz, A. (2017). Making the EU legislation on invasive species a conservation success. Conservation Letters, 10(1), 112-120. https://doi.org/10.1111/conl.12214

Veganzones-Varoudakis, M. A., \& Nguyen, H. T. M. (2018). Investment climate, outward orientation and manufacturing firm productivity: New empirical evidence. Applied Economics, 50(53), 5766-5794. https://doi.org/10.1080/00036846.2018.1488065 
Iryna PANOVA, Ph.D. in Law, Associate Professor, Kharkiv National University of Internal Affairs, Ukraine ORCID ID: orcid.org/0000-0003-4325-5428

Olha ANDRIIKO, Doctor Juridical Sciences, Professor, Institute of State and Law of National Academy of Sciences of Ukraine ORCID ID: orcid.org/0000-0002-7507-3090

Liudmila KYSIL, PhD in Law, Senior Scientific Reseacher V.M.Koretsky Institute of state and law of National Academy of Sciences of Ukraine

ORCID ID: orcid.org/0000-0001-7986-0967

Tetyana KURYLO, Doctor of Law, Associate Professor, Lviv State University of Internal Affairs, Ukraine ORCID ID: orcid.org/0000-0003-0039-5121

Yuliya URALOVA, PhD, Associate Professor of the Civil Law and Procedure Department Vasyl' Stus Donetsk National University, Ukraine

ORCID ID: orcid.org/0000-0003-1065-2099

Register for an ORCID ID:

https://orcid.org/register

This work is licensed under the Creative Commons Attribution International License (CC BY). http://creativecommons.org/licenses/by/4.0/ 